\title{
Changing media minds: a practical guide
}

\author{
Deborah Hart and Jill Phillipson
}

In October 1998, the Royal College of Psychiatrists launched a new five-year campaign entitled 'Changing Minds: Every Family in the Land', which aims to tackle the problems of stigmatisation of and discrimination against people with mental disorders. As part of the campaign, the College recently sent to the membership a 'Declaration of Intent', asking members to sign up to the Campaign's aims and to indicate their support for it. To date we have received more than 2000 signatures and would like to encourage all readers of the Bulletin to return their forms immediately. If you have lost your declaration form please contact the External Affairs Department.

The media are key influencers of public opinion. In the Declaration of Intent, we specify that the campaign will challenge inaccurate representations, in the media and elsewhere, based on stigmatising attitudes and stereotypes. myths, misunderstandings and discriminatory attitudes. One important way of achieving this is by actively complaining, both as an individual and as a member of the College.

All too regularly, the External Affairs Department receives complaints from the membership about stigmatisation, both of mental disorders and of psychiatry itself. One of the most common concerns is the misuse of the word 'schizophrenic' to imply ambivalence. A recent example of this was Jenni Murray on Radio 4's Woman's Hour, who interviewed the novelist Michelle Roberts and described her double life between England and France as 'schizophrenic'. Clearly the term was not meant in a derogatory way, but its use was inaccurate and does not help listeners to understand mental disorders.

We were concerned over an item on Channel 4 News on the rationing of the newer antipsychotic drugs, which featured an old black and white film clip of unmodified electroconvulsive therapy being administered. In response to this, we immediately telephoned the Complaints Department at Channel 4 , only to be told that they would make a note of our concerns but that we must write in personally. Unless all of us react to these inaccuracies in the media, nothing will ever change and stigmatisation will persist.

\section{How to complain directly: a practical guide}

\section{Radio and television}

Seize the moment - it is much better to telephone the television or radio station while the programme is being transmitted or as soon as possible afterwards. As was our recent experience, the telephone complaint will be logged but will have more impact if it is followed by a letter. It takes a little extra effort and time to send a follow-up letter, but it is well worth it. Complaints are taken very seriously and the more there are, the more likely we are to change media attitudes and behaviour.

\section{Helpful addresses}

$B B C$ : The Broadcasting Standards Commission, 7 The Sanctuary, London SW1P 3JS (Tel: 0171 233 0544): BBC Programmes (Viewers and Listeners correspondence): BBC Villiers House, The Broadway, London W5 2PA or telephone the BBC Information Office on Tel: 01817438000 (always give the programme title, transmission date and time). Alternatively, write to The Programme Complaints Unit, Broadcasting House, London WIA IAA.

Commercial Television and Radio: Complaints about ITV, Channels 4 and 5, satellite and cable should be directed to the individual station. Channel 4 has a 24-hour duty office (Tel: 0171 306 8333). Similarly, Channel 5 has a duty office on 0345050505 . Or write to: The Independent Television Commission, 33 Foley Street, London W1P 7LB (Tel: 0171255 3000). They also deal with complaints about programmes and adverts on ITV, Channels 4 and 5, satellite and cable. For complaints about independent radio, contact The Radio Authority, Holbrook House, 14 Great Queen Street, London WC2B 5DG (Tel: 0171430 2724).

Advertising, newspaper and magazine articles Don't delay - as soon as you see a stigmatising article or advert, you can do the following immediately:

(a) Write to the editor of the publication. 
(b) For advertisement, write directly to the Managing Director of the company concerned.

(c) Write directly to the journalist responsible for the story.

(d) Write to the 'Letters' page of the newspaper, marking your letter 'for publication' and send or fax it as soon as possible, preferably on the same day as the article appeared.

You can take your complaint further by writing to the Press Complaints Commission, 1 Salisbury Square, London EC4Y 8AE (Tel: 0171353 3732), which looks at complaints about the editorial contents of magazines and newspapers. For complaints about advertisements, contact the Advertising Standards Authority, 2 Torrington Place, London WC1E 7HW (Tel: 0171580 5555).

It is not only the College that is concerned about the stigmatising portrayal of mental disorders in media. As part of their 'Respect' campaign, MIND have established a project encouraging their members to become "Mind Media Guardians'. This scheme has the endorsement of the Press Complaints Commission and further details are available from MIND on Tel:
01812152499 . Similarly, a number of user and carer organisations, which include such groups as the Manic Depression Fellowship, National Schizophrenia Fellowship and Mental After Care Association, have established a Mediawatch Campaign. For further information, contact the Mental Health Foundation on Tel: 0171580 0145.

In order to assess how well the membership is developing a systematic monitoring and complaints procedure, the External Affairs Department would welcome copies of your correspondence and a note of your telephone calls. Please send these to Deborah Hart at the College or E-mail: dhart@rcpsych.ac.uk.

Changing Minds is planning to set up its own 'media watch' campaign - so watch this space.

*Deborah Hart, Head of External Affairs and Jill Phillipson, External Public Relations Adviser. External Affairs Department, Royal College of Psychiatrists, 17 Belgrave Square, London SW1X 8PG

*Correspondence

\section{Late-Onset Mental Disorders Edited by Andreas Marneros}

The association between certain diseases and particular periods of life has been studied since the 19th century, yet attempts to delineate categories of mental disorder unique to old age have floundered over the decades and the debate continues.

After an historical overview, this book looks at differences between early-onset and late-onset disorders. Is there anything special about old-age depression? Are there any atypical features of late-onset schizophrenia? Besides questions concerning depression, dementia and psychosis, the book looks at sleep disturbances in the elderly, anxiety, use of anti-dementia drugs, antidepressants and neuroleptics in old age, and psychological processes.

It will be of particular interest to old age psychiatrists, liaison psychiatrists, epidemiologists, university lecturers and medical historians.

$$
\text { June 1999, 208pp, Paperback, ISBN } 190124226 \text { 9, f25.00 }
$$

Available from Book Sales, Royal College of Psychiatrists, 17 Belgrave Square, London SWIX 8PG Tel +44 (0) 1712352351 (extension 146) $9.30 a m-2$ pm, Fax +44 (0) 1712451231

http://www.rcpsych.ac.uk 